\title{
Sedation for Colonoscopy: Comparison of Remifentanil and Alfentanil Combined with Propofol/Midazolam
}

\author{
Kolonoskopi için Sedasyon: Propofol/Midazolam ile Kombine Edilen Remifentanil ve \\ Alfentanil'in Karșılaștırılması
(D) Şule Arıcan¹, (D) Faruk Çiçekçi², (D) Gülçin Hacıbeyoğlu¹, (D) Çiğdem Sizer³, (D) Sema Tuncer Uzun¹, (D) Ramazan Dertli4 (D) Muharrem Keskin4

${ }^{1}$ Necmettin Erbakan University Faculty of Medicine, Department of Anaesthesiology, Konya, Turkey

2Selçuk University Faculty of Medicine, Department of Anaesthesiology, Konya, Turkey

${ }^{3}$ Numune Hospital, Clinic of Anaesthesiology, Konya, Turkey

${ }^{4} \mathrm{Necmettin}$ Erbakan University Faculty of Medicine, Department of Gastroenterology, Konya, Turkey

\begin{abstract}
Introduction: Different drug combinations are used in patients who underwent colonoscopy for safe sedation and early discharge. Remifentanil and alfentanil are short-acting narcotic analgesic agents. A short-acting anxiolytic agent, midazolam has a potent sedative efficiency when combined with narcotic analgesics. In this study, we aimed to compare the effectiveness of the two opioids that have not been previously compared in the literature, combined with propofol/midazolam in patients who underwent colonoscopy.
\end{abstract}

Methods: One hundred eighty-nine patients aged over 18 years who underwent diagnostic and/or therapeutic colonoscopy were included in the study. $1 \mathrm{mg}$ midazolam $+5 \mu \mathrm{g} \mathrm{kg}-1$ alfentanil $+1 \mathrm{mg} \mathrm{kg-1}$ propofol were administered in the alfentanil group (group A), while $1 \mathrm{mg}$ midazolam $+0.1 \mu \mathrm{g} \mathrm{kg}-1$ min-1 remifentanil + 1 mg kg-1 propofol were administered in the remifentanil group (group R). Hemodynamic data, Modified Steward scale (MSS), Visual Analog scale (VAS), additional propofol doses, total procedure time, awake time, recovery time, and side effects were recorded during the procedure. After the procedure, all patients were transferred to the recovery room, and the Modified Aldrete scale (MAS) values were recorded.

Results: There was a statistically significant difference between the groups in terms of total propofol and additional propofol doses $(p<0.05)$, with additional propofol dose being higher in group $A$ compared to group $R(p<0.05)$. Awake time was similar between the groups. Recovery time was longer in group A compared to group $R(p<0.05)$. No significant difference was observed in the side effects between both groups.

Conclusion: Although the low dose of midazolam combined with propofol/remifentanil and propofol/alfentanil provided adequate sedation and analgesia, we believe that remifentanil is an ideal choice for daily procedures like colonoscopy because of its advantages resulting from its pharmacological properties. Keywords: Alfentanil, colonoscopy, remifentanil, sedation
ÖZ

Amaç: Kolonoskopi işlemi uygulanan hastalara güvenli sedasyon ve erken taburculuk amacıyla farklı ilaç kombinasyonları kullanılmaktadır. Remifentanil ve alfentanil kısa etkili narkotik analjezik ajanlardır. Kısa etkili bir anksiyolitik ajan olan midazolam narkotik analjeziklerle kombine edildiğinde güçlü bir sedadif etkinliğe sahiptir. Kolonoskopi işlemi altındaki hasta da sedasyon amacıyla literatürde karșılaștırılmamıș 2 opiodin propofol/midazolam ile kombinasyonunun etkinliğini karşılaștırmayı amaçladık.

Yöntemler: Çalıșmaya tanı ve/veya tedavi amaçlı kolonoskopi uygulanan 18 yaş üzeri yüz seksen dokuz hasta alındı. Alfentanil grubunda (grup A) $1 \mathrm{mg}$ midazolam $+5 \mu \mathrm{g} \mathrm{kg}-1$ alfentanil $+1 \mathrm{mg} \mathrm{kg}-1$ propofol ve remifentanil grubuna (grup R) $1 \mathrm{mg}$ midazolam $+0.1 \mu \mathrm{g} \mathrm{kg} \mathrm{-1} \mathrm{dk-1} \mathrm{remifentanil} \mathrm{+}$ $1 \mathrm{mg} \mathrm{kg-1}$ propofol uygulandı. Hemodinamik veriler, Modifiye Steward skalası (MSS), Görsel Analog skala (VAS), ek propofol dozları, toplam işlem süresi, uyanma süresi, iyileșme süresi ve yan etkiler ișlem sırasında kaydedildi. İșlem sonrası tüm hastalar derlenme odasına transfer edildi ve Modifiye Aldrete skalası (MAS) değerleri kaydedildi.

Bulgular: Total propofol ve ek propofol dozlarında gruplar arasında istatistiksel olarak anlamlı farklılık saptanmıștır $(p<0.05)$, ve grup $A$ da grup $R$ ye göre propofol ek dozunun daha yüksek olduğu gözlenmiștir $(p<0.05)$. Uyanma süresi gruplar arasında benzerdi. Derlenme süresinin grup A'da grup R'ye göre daha uzun olduğu tespit edildi $(p<0.05)$. Gruplar arasında yan etkilerde anlamlı farklılık saptanmamıștır.

Sonuç: Propofol/remifentanil ve propofol/alfentanil ile kombine edilen düşük doz midazolam etkili sedasyon ve analjezi sağlamasına rağmen, remifentanilin, farmakolojik özelliklerinden doğan avantajları nedeniyle kolonoskopi gibi günlük işlemler için ideal bir seçim olduğuna inanıyoruz.

Anahtar Kelimeler: Alfentanil, kolonoskopi, remifentanil, sedasyon
Address for Correspondence/Yazıșma Adresi: Șule Arıcan MD, Necmettin Erbakan University Faculty of Medicine, Department of Anaesthesiology, Konya, Turkey

Phone: +90 3322236600 E-mail: drsulearican@hotmail.com ORCID ID: orcid.org/0000-0002-8634-1150

Cite this article as/Atıf: : Arıcan Ș, Çiçekçi F, Hacıbeyoğlu G, Sizer Ç, Tuncer Uzun S, Dertli R, Keskin M. Sedation for Colonoscopy: Comparison of Remifentanil and Alfentanil Combined with Propofol/Midazolam. İstanbul Med J 2019; 20(6): 512-8.

(c) Copyright 2019 by the Istanbul Training and Research Hospital/istanbul Medical Journal published by Galenos Publishing House.

(C) Telif Hakkı 2019 Istanbul Ĕgitim ve Araștırma Hastanesi/Istanbul Tıp Dergisi, Galenos Yayınevi tarafından basılmıștır.
Received/Geliș Tarihi: 19.07.2019 Accepted/Kabul Tarihi: 05.10.2019 


\section{Introduction}

Currently, colonoscopy is a standard imaging procedure used for the diagnosis, treatment, and follow up of many colorectal diseases (1). Safe sedation and early discharge are the essential parameters in daily procedures requiring sedation such as colonoscopy (2). Considering the increase in colonoscopies, there is an increasing demand for intravenous (IV) analgesics and sedatives. Increased demand and recent developments in the pharmacological area lead to the use of drugs with a broad therapeutic index, and the drugs are rapidly metabolized to inactive metabolites (3). The agents used for sedation should not cause respiratory depression, hemodynamic instability, and severe side effects (2). Therefore, propofol is increasingly used in many countries due to its excellent effect in moderate sedation, very short terminal half-life, rapid discharge, and rapid recovery from sedation $(3,4)$. Remifentanil is a short-acting narcotic analgesic with a short elimination time under 10 minutes. Biotransformation is rapid and complete; therefore, the infusion time has a minimal effect on the awake time of patients (5). Alfentanil is a narcotic analgesic that has a rapid effect onset very short action time, and potency approximately $1 / 3$ of fentanyl. Midazolam is a short-acting anxiolytic agent with a strong sedative effect when combined with IV narcotic agents. The combination of propofol with a low dose of short-acting opioids and benzodiazepine is a good alternative for safe sedation and analgesia without increasing the rate of adverse effects. The total propofol dose is reduced due to the synergistic effect of the drugs in this combination (6-9).

Unlike the other studies in adult patients who underwent colonoscopy procedure, in the present study, we aimed to compare additional propofol dose, awake times, recovery times, and side effects of low dose midazolam combined with propofol/alfentanil and propofol/ remifentanil, in adult patients who underwent colonoscopy procedure.

\section{Methods}

The study was performed with the approval of the Necmettin Erbakan University Meram Faculty of Medicine Ethical Committee (decision no: 2017/1109) in concordance with the Declaration of Helsinki. Written informed consent was received from all patients. In this study, a prospectively stored database and medical records of patients who underwent diagnostic and/or therapeutic colonoscopy in Necmettin Erbakan University Meram Faculty of Medicine between January 2017 and November 2017 were reviewed. We used G Power Software to determine the sample size. The sample size was calculated based on recovery time (10-12). We found that a total of 180 patients (90 patients for each group) would be needed to compare the two groups with $90 \%$ power, 5\% type I error level, and 25\% effect size for the F test. We enrolled 200 patients in accounting for the possibility of exclusion.

Patients who were aged over 18 years, had American Society of Anesthesiologists (ASA) physical status I-III and who underwent colonoscopic examination for diagnosis and treatment under sedation with a low dose of midazolam combined with propofol/remifentanil and propofol/alfentanil, were included in the study. Patients aged less than 18 years, having ASA IV-V and patients with opioid and/ or sedative addictions, pregnancy, psychiatric/emotional disorder, patients undergoing an emergency or inpatient colonoscopy, and other endoscopic procedures in addition to colonoscopy were excluded from the study. Patients with an incomplete procedure for any reason and patients with inadequate bowel preparation were excluded from the final analysis.

Two hundred patients who underwent colonoscopy under sedation with the combination of remifentanil-propofol-midazolam or alfentanilpropofol-midazolam were included in the study. Eleven patients were excluded from the final analysis (Figure 1).

The age, gender, body mass index, and ASA of one hundred eighty-nine patients were recorded. All colonoscopy procedures were performed by the same experienced endoscopist using high-resolution video colonoscopies (EC-530WL3, Fujinon, Fujifilm Corporation, Japan). All patients were monitored according to the ASA standards in the colonoscopy room. Heart rate (HR), mean blood pressure (MBP), and peripheral oxygen saturation $\left(\mathrm{SpO}_{2}\right)$ were measured and recorded (Petaş KMA 800). Measurements were repeated every 5 minutes during the procedure. Intranasal oxygen $\left(6 \mathrm{~L} \mathrm{~min}^{-1}\right)$ was administered to the patients. After peripheral IV cannulation, $6 \mathrm{~mL} \mathrm{~kg}^{-1} \mathrm{hr}^{-1}$ standard saline infusion was initiated, and $1 \mathrm{mg}$ midazolam $\left(1 \mathrm{mg} \mathrm{mL}^{-1}, 5 \mathrm{~mL}\right.$; Deva Holding, İstanbul, Turkey) was administered to all patients. Sedation was induced with $5 \mu \mathrm{g} \mathrm{kg}^{-1}$ alfentanil (Rapifen ${ }^{\circledR}$ Johnson \& Johnson, İstanbul, Turkey) $+1 \mathrm{mg} \mathrm{kg}^{-1}$ propofol (Propofol, Fresenius, İstanbul, Turkey) in the alfentanil group (group A), and $0.1 \mu \mathrm{g} \mathrm{kg}^{-1} \mathrm{~min}^{-1}$ remifentanil (Ultiva, Glaxo Smith Kline, İstanbul, Turkey) $+1 \mathrm{mg} \mathrm{kg}^{-1}$ propofol in the remifentanil group (group R). Propofol (10-20 mg) was added according to the Modified Steward scale (MSS) in order to maintain at 2-4 (Appendix 1) (13).

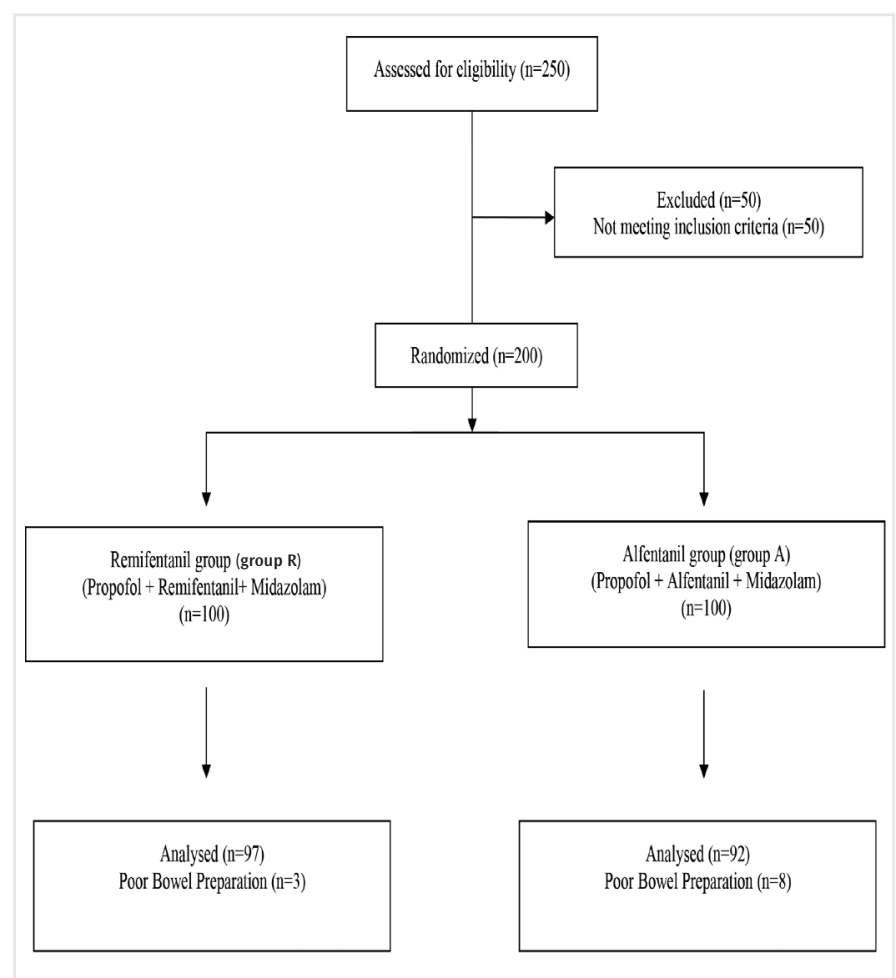

Figure 1. Flow diagram of the study 
Additional propofol doses were recorded. The pain level of the patients was assessed by a Visual Analog scale (VAS) [no pain (0) - severe pain (10)] at every 5-minute interval during the colonoscopy procedure. Systolic blood pressure under $90 \mathrm{mmHg}$ was accepted as hypotension, and HR under 50 beats min $^{-1}$ was accepted as bradycardia. The fluid infusion rate of patients who developed hypotension was increased by three folds. An additional fluid infusion was continued for 10 minutes. Vasopressor (ephedrine) administration was planned in patients who had no response to liquid infusion. Atropine $\left(0.01 \mathrm{mg} \mathrm{kg}^{-1}\right.$; IV) was given to patients in case of bradycardia. $\mathrm{SpO}_{2}$ less than $90 \%$ was accepted as hypoxemia. When $\mathrm{SpO}_{2}$ was determined less than $90 \%$ during the followup, a jaw thrust maneuver was performed. If $\mathrm{SpO}_{2}$ persisted as less than 85\% despite the jaw thrust maneuver, all of the infusions were stopped, and assisted ventilation was performed. It was planned that, if $\mathrm{SpO}_{2}$ less than $85 \%$ took more than 30 seconds, then the procedure would be interrupted, and an antagonist agent (flumazenil, naloxone) would be

\begin{tabular}{|ll|}
\hline Appendix 1 & Airway (0-3) \\
Patient Sedation Score & $\begin{array}{l}\text { 3- Opens mouth, coughs on } \\
\text { command }\end{array}$ \\
Consciousness 01234 & 2- Opens mouth, clear airway, \\
weak cough
\end{tabular}

administered. Cardiopulmonary side effects (hypotension, bradycardia, and hypoxemia), nausea, vomiting, and the treatment were recorded in all patients. The colonoscopic procedure was waited for 60 seconds after the administration of the drugs. Total procedure time was defined as the time between the initiation and completion of colonoscopy. Awake time was defined as the time from the end of colonoscopy until consciousness (0-4) score 4, according to the MSS, and the recovery time was defined as the time from the end of colonoscopy until Modified Aldrete scoring (MAS) 10 was achieved. After the procedure, all patients were transferred to the recovery room, and vital findings and MAS values were recorded. MAS, which is a 10-point scale, was used for assessing the recovery time (Appendix 2) (12). Patients were followed up until MAS 10 and then discharged.

\begin{tabular}{|c|c|}
\hline \multirow[b]{2}{*}{ Modified Aldrete Scores } & Circulation (0-2) \\
\hline & $\begin{array}{l}\text { 2- Blood Pressure } \pm 20 \% \text { of } \\
\text { Pre-anesthetic level }\end{array}$ \\
\hline \multirow{3}{*}{$\begin{array}{l}\text { Activity (0-2) } \\
\text { 2- Able to move four } \\
\text { extremities voluntarily or on } \\
\text { command }\end{array}$} & 1- Blood Pressure + 20-50\% of \\
\hline & Pre-anesthetic level \\
\hline & $\begin{array}{l}0 \text { - Blood Pressure } \pm 50 \% \text { of } \\
\text { Pre-anesthetic level }\end{array}$ \\
\hline \multirow{2}{*}{$\begin{array}{l}\text { 1- Able to move two } \\
\text { extremities voluntarily or on } \\
\text { command }\end{array}$} & Consciousness $(0-2)$ \\
\hline & 2- Fully awake \\
\hline \multirow{2}{*}{$\begin{array}{l}0 \text { - Able to move } 0 \text { extremities } \\
\text { voluntarily or on command }\end{array}$} & 1- Arousable on calling \\
\hline & 0 - Not responding \\
\hline \multirow{5}{*}{$\begin{array}{l}\text { Respiration }(0-2) \\
\text { 2- Able to deep breathe and } \\
\text { cough freely } \\
\text { 1- Dyspnea or limited } \\
\text { breathing } \\
0 \text { - Apnea }\end{array}$} & \\
\hline & $0_{2}$ Saturation $(0-2)$ \\
\hline & $\begin{array}{l}\text { 2- Maintains }>92 \% \text { on room } \\
\text { air }\end{array}$ \\
\hline & $\begin{array}{l}\text { 1- Needs } \mathrm{O}_{2} \text { inhalation to } \\
\text { maintain } \mathrm{O}_{2} \text { saturation }>90 \%\end{array}$ \\
\hline & $\begin{array}{l}0 \text { - Saturation }<90 \% \text { even with } \\
\text { supplemental oxygen }\end{array}$ \\
\hline
\end{tabular}

Table 1. Basic characteristics of the study groups

\begin{tabular}{l}
\hline Characteristics \\
Age (mean \pm SD) (year) \\
\hline Gender (male/female) \\
\hline
\end{tabular}

BMI (mean \pm SD) $\left(\mathrm{kg} / \mathrm{m}^{2}\right)$

\section{ASA classification $\mathbf{n}(\%)$}

II

III

Baseline MBP, (mean \pm SD), $\mathrm{mmHg}$

Baseline HR, (mean $\pm S D)$, beat $/ \mathrm{min}$

Baseline $\mathrm{SpO}_{2}$, (mean $\pm \mathrm{SD}$ ), \%
Remifentanil group, $(\mathbf{n}=97)$

$53.97 \pm 14.23$

$50 / 47$

$24.30 \pm 4.3$

37 (38.1\%)

42 (43.3\%)

18 (18.6\%)

$88.45 \pm 9.28$

$81.25 \pm 11.46$

$97.03 \pm 1.25$

\begin{tabular}{|l|}
\hline Alfentanil group, $(\mathbf{n}=\mathbf{9 2}$ \\
\hline $51.92 \pm 15.11$ \\
\hline $44 / 48$ \\
\hline
\end{tabular}

$25.01 \pm 5.2$

$36(39.1 \%)$

$38(41.3 \%)$

$18(19.6 \%)$

$85.56 \pm 9.91$

$81.14 \pm 12.51$

$97.86 \pm 1.35$ p

0.344

-

0.516

\begin{tabular}{|l}
\hline- \\
\hline- \\
\hline- \\
\hline 0.040 \\
\hline 0.947 \\
\hline 0.839 \\
\hline
\end{tabular}

BMI: body mass index, ASA: American Society of Anesthesiology, MBP: mean blood pressure, HR: heart rate, $\mathrm{SpO}_{2}$ : peripheral oxygen saturation, $\mathrm{n}$ : number of patients, SD: standart deviation 


\section{Statistical Analysis}

Data obtained were analyzed using SPSS 20.00 software (Statistical Package for Social Sciences Inc. Chicago, IL). The continuous variables are expressed as mean \pm standard deviation (SD) or number (\%); whereas categorical variables are expressed as number and percentages (\%). The normality of the data was tested with Kolmogorov-Smirnov test. Since there was no normal distribution, continuous variables were analyzed with the Mann-Whitney $U$ test. Comparison of two groups and analysis of categorical variables were made using the chi-square test. $P$ values $<0.05$ were considered statistically significant.

\section{Results}

A total of 200 patients who underwent colonoscopy under sedation were included in the study. Eight patients from group A and three patients from group $R$ were excluded from the study because of inadequate bowel preparation. Ninety-nine of the patients were male (52\%), and the two groups were similar in terms of gender $(p>0.05)$. The baseline characteristics of the patients were the same in the two groups (Table 1).

A statistically significant difference was determined between total propofol doses and additional propofol doses, with propofol doses being higher in group $A$ than in group $R(p<0.05)$. There was no statistically significant difference in awake time between the groups $(p>0.05)$. Recovery time was longer in group $A$ than in group $R(p<0.05)$. The mean total dose of sedatives and analgesics administered during mean procedural times are presented in Table 2.

In both groups, MBP and HR values decreased compared to baseline values, but mean arterial pressure, $\mathrm{HR}$, and $\mathrm{SPO}_{2}$ values were not statistically significantly different between the groups.

No statistically significant difference was determined in the VAS and MSS scores between the groups. The VAS score range was 0-3 and 0-4 (mean \pm SD: $0.16 \pm 0.45 / 0.21 \pm 0.41$ ), while MSS score range was $1-3$ and 1-4 (mean \pm SD: $1.68 \pm 0.87 / 1.8 \pm 0.98$ ) in the remifentanil and the alfentanil group, respectively.

There was no statistically significant difference between the groups in the MBP and $\mathrm{SPO}_{2}$ and $\mathrm{HR}$ values in the recovery room. Though a statistically significant difference was determined between the groups in MAS recovery scale values recorded in the recovery room (RR) at RR $3^{\text {rd }}$, $R R 5^{\text {th }}, R R 10^{\text {th }}$, and $R R 15^{\text {th }}$ minutes $(p<0.05)$, while no difference was observed at other time points (Figure 2).

There was no bradycardia in any patients in group $A$, but two patients experienced bradycardia in group $R(p=0.166)$. Three patients $(3.3 \%)$ in group $A$ and five patients (5.2\%) in group $R$ developed hypotension $(p=0.721)$, and none of the patients required a vasopressor agent. The numbers of patients who experienced hypoxemia and underwent interventions were similar between the two groups. Sedation related complications are given in Table 3.

\section{Discussion}

In this study, though a significant difference was determined in additional propofol dose and recovery times compared to the remifentanil group and alfentanil group in adult patients during the colonoscopic procedure, there was no difference in awake times and side effects.

The use of propofol as the single agent has recently occupied a significant place for sedation of the patients under colonoscopy because of rapid awake and recovery times it provides and also its safety (14). However, the analgesic effect of propofol is limited, and higher doses that increase the risk of deep sedation are required when it is used as a single agent.

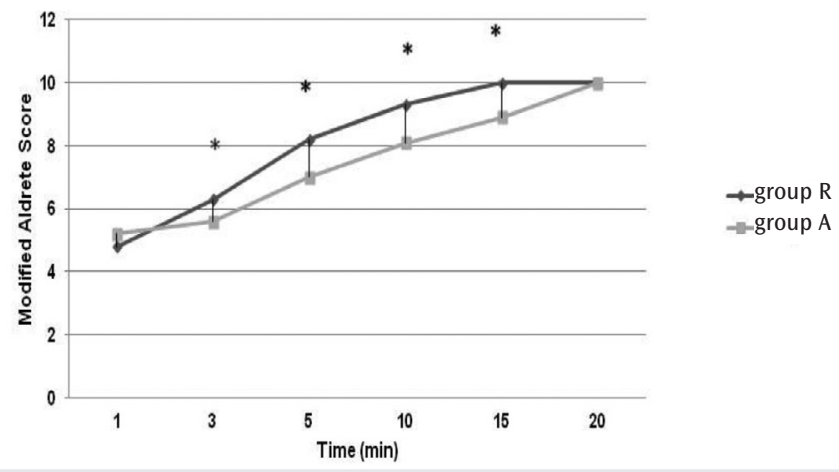

Figure 2. Comparison of MAS between groups

*: $p<0.05$, group R: remifentanil group, group A: alfentanil group, RR: recovery room, MAS: modified Aldrete scores

\section{Table 2. Sedative/analgesic doses, procedure-related times}

\begin{tabular}{|l|l|l|l|}
\hline Total dose, mean $\mathbf{\pm}$ SD & Remifentanil group, $(\mathbf{n = 9 7 )}$ & Alfentanil group, (n=92) \\
\hline Midazolam, $\mathrm{mg}$ & 1 & 1 \\
\hline Remifentanil, $\mu \mathrm{cg}$ & $81.42 \pm 34.85$ & - \\
\hline Alfentanil, $\mu \mathrm{cg}$ & - & $371.08 \pm 73.37$ \\
\hline Total propofol, $\mathrm{mg}$ & $88.17 \pm 22.97$ & $110.11 \pm 41.26$ \\
\hline Additional propofol, mg & $13.96 \pm 21.34$ & $36.89 \pm 42.56$ \\
\hline Procedure related times (mean \pm SD) min & & $<0.001^{*}$ \\
\hline Total procedure time & $12.07 \pm 4.07$ & $13.15 \pm 3.57$ \\
\hline Awake time & $5.9 \pm 0.89$ & $6.1 \pm 1.10$ \\
\hline Recovery time & $12.36 \pm 1.42$ & $14.68 \pm 1.41$ \\
\hline n: number of patients, * $p<0.05$, SD: standart deviation, min: minimum & 0.054 \\
\hline
\end{tabular}


Table 3. Complications associated with the sedation during, $\mathbf{n}(\%)$

\begin{tabular}{|c|c|c|c|}
\hline & Remifentanil group, $(n=97)$ & Alfentanil group, $(n=92)$ & p \\
\hline \multicolumn{4}{|l|}{ Hypoxemia } \\
\hline $\mathrm{SpO}_{2}<90$ & $2(2.1)$ & $5(5.4)$ & 0.269 \\
\hline $\mathrm{SpO}_{2}<85$ & $6(6.2)$ & $2(2.2)$ & 0.280 \\
\hline Chin lift & $2(2.1)$ & $5(5.4)$ & 0.269 \\
\hline Mask ventilation & $6(6.2)$ & $2(2.2)$ & 0.280 \\
\hline Systolic hypotension $<90 \mathrm{mmHg}$ & $5(5.2)$ & $3(3.3)$ & 0.721 \\
\hline Use of vasopressors & 0 & 0 & 0.501 \\
\hline Bradycardia $<50$ beats/min & $2(2.1)$ & 0 & 0.166 \\
\hline Vomiting & 0 & 0 & 0.501 \\
\hline
\end{tabular}

Bolus administration related to a short half-life of propofol facilitates the occurrence of "sedation waves" via which deep sedation peaks and respiratory depression may be replaced by the risk for superficialization and agitation during colonoscopy (15). The addition of opioids and benzodiazepine to propofol for pain control during colonoscopy procedure increases the sedative effects of propofol, and thus provides avoiding of propofol overdose (16).

Patients sedated only with propofol need higher dose additional propofol than the patients sedated with the combination of alfentanil/ midazolam and with midazolam alone (9). In a study with incremental propofol administration in the midazolam/fentanyl and midazolam/ fentanyl/ketamine groups, propofol dose was found to be significantly lower in the second group (11). In the pre-anesthetic administration of fentanyl and propofol with and without midazolam, propofol consumption is lower in the midazolam $\left(0.05 \mathrm{mg} \mathrm{kg}^{-1}\right)$ group (17).

In our study, an additional dose of propofol was lower in the remifentanil group, compared to the alfentanil group.

In the case of midazolam alone for sedation, duration of hospitalization, and recovery time are prolonged (9). Whereas recovery times were similar in the combination of $1-2.5 \mathrm{mg}$ midazolam with propofol and opioids $(6,9,10)$, recovery time was prolonged when midazolam dose was used as $2.5 \mathrm{mg}$ and higher (9).

The slow metabolization of benzodiazepines could prolong the recovery time, reducing the turnover rate and efficiency of the endoscopic unit (1). In the present study, midazolam was administered in all patients at $1 \mathrm{mg}$ dose because of its effect on recovery time.

In a study comparing safety and effectiveness of small dose alfentanil and fentanyl at balanced propofol sedation for deep sedation, recovery time was around 15 minutes (10). Similarly, recovery time was found as around 15 minutes in balanced propofol sedation targeting moderate sedation for colonoscopy (1). It was underlined for the same result obtained in these two studies that only $1 \mathrm{mg}$ administration of midazolam in the second study might provide an advantage on recovery time (10). In the present study, midazolam used at $1 \mathrm{mg}$ revealed the difference between action times of opioids. Both short action time of remifentanil and a low additional dose of propofol have been effective in the short recovery time in group $\mathrm{R}$.
In a study that combined midazolam and propofol with alfentanil, fentanyl, and remifentanil in order to maintain sedoanalgesia during cardioversion, it was shown that time of achieving MAS 8 was shortest in the remifentanil group and longest in the fentanyl group, and there was no statistical difference between alfentanil and remifentanil groups (8). In this study, no difference was found in the alfentanil and remifentanil since the additional dose of propofol was not administered, while in our study, this time was longer because of the high additional dose of propofol in the alfentanil group.

In our study, VAS and MSS values were observed as minimal in both groups, compatible with the literature (10).

The use of sedative agents improves endoscopic performance and increases compliance with the procedure. However, the probability of moderate complications related to sedation should be considered $(18,19)$. Respiratory depression caused by sedation and hemodynamic instability can occur during colonoscopy, but the prevalence of adverse effects requiring antagonist agent is low (20). Drug-induced hypoventilation may cause hypoxemia and carbon dioxide retention. Pulse-oximetry is a useful indicator of oxygenation (21). When propofol is administered concomitantly with an opioid, it causes less respiratory depression (8). In our study, patients were monitored with pulse oximetry, and no significant difference was observed in terms of $\mathrm{SpO}_{2}$ between the two groups. In our study, the blood pressure of patients was monitored non-invasively before, during, and after the procedure. Following drug administration, a reduction was observed in MBP and $H R$ values compared to basal in both of the groups. There was no statistically significant difference in the MBP and $\mathrm{HR}$ values between the groups at other times. Generally, $90 \mathrm{mmHg}$ systolic blood pressure is adequate to perfuse tissues in the lying position. Lower blood pressure values cause inadequate perfusion and require intervention. A decline in HR and/or cardiac output volume decreases the blood pressure at the same time. Therefore, blood pressure and HR should be recorded before, during, and after the endoscopy. Also, a more profound fall in blood pressure may occur in the hypovolemic patient. Volume support can be beneficial; therefore, it can be suggested in order to prevent hypotension due to propofol (21).

None of our patients required antagonist agents, and there was no difference related to cardiovascular complications between the two 
groups. The complication rate was similar to other studies, complications were treated conservatively, and there was no need for endotracheal intubation $(8,10)$.

There was no nausea and vomiting in our study groups. This might be due to the antiemetic effect of propofol. Studies have reported that propofol and the opioid combination provided not only analgesia and amnesia, but also decreased the frequency of nausea and vomiting $(14,22)$. Nausea and vomiting are the common adverse effects of opioids. Excessive distension of the stomach and colon during the procedure can also cause nausea and vomiting (21).

The sedative patients were discharged from the RR when they met discharge criteria (23). The probability of early discharge from PACU is an essential feature in the care of outpatients and produces better service and lower costs (24). Time to discharge was determined as 15 minutes according to the Modified Post-anesthetic Discharge Criteria (11). In another study, time to discharge was determined as 20 minutes in patients administered deep sedation (25). In our study, time to discharge was determined as 15 minutes.

\section{Study Limitation}

There were limitations to our study. First, this study was performed in a center with only one gastroenterologist and anesthesiologist, and follow up was performed by an independent research nurse. Therefore, the results were difficult to generalize. A multiple-center clinical trial might solve this limitation.

\section{Conclusion}

In the present study, a low dose of midazolam combined with propofol/ remifentanil and propofol/alfentanil provided effective sedation and analgesia. Less propofol consumption and shorter recovery times were observed in the remifentanil group. We believe that low dose midazolam combined with propofol/remifentanil is a vital anesthetic option in pain control during colonoscopy and can be safely and effectively used in daily practice because of its advantages related to the pharmacological characteristics of remifentanil.

Ethics Committee Approval: The study was performed with the approval of the Necmettin Erbakan University Meram Faculty of Medicine Ethical Committee (decision no: 2017/1109).

Informed Consent: Written informed consent was received from all patients.

Peer-review: Externally peer-reviewed.

Author Contributions: Surgical and Medical Practices - R.D., M.K.; Concept - S.A., C.S.; Design - \$.A., C.S.; Data Collection and/or Processing - F.C., G.H., R.D., M.K.; Analysis and/or Interpretation - G.H., R.D., M.K.; Literature Search - F.C.., G.H., C.S.; Writing Manuscript - Ş.A., G.H., S.T.U.

Conflict of Interest: No conflict of interest was declared by the authors.

Financial Disclosure: The authors declared that this study received no financial support.

\section{References}

1. VanNatta ME, Rex DK. Propofol alone titrated to deep sedation versus propofol in combination with opioids and/or benzodiazepines and titrated to moderate sedation for colonoscopy. Am J Gastroenterol 2006; 101: 2209-17.

2. McQuaid KR, Laine L. A systematic review and meta-analysis of randomized, controlled trials of moderate sedation for routine endoscopic procedures. Gastrointest Endosc 2008; 67: 910-23.

3. Pambianco DJ, Borkett KM, Riff DS, Winkle PJ, Schwartz HI, Melson TI, et al. A phase IIb study comparing the safety and efficacy of remimazolam and midazolam in patients undergoing colonoscopy. Gastrointest Endosc 2016; 83: 984-92.

4. Triantafillidis JK, Merikas E, Nikolakis D, Papalois AE. Sedation in gastrointestinal endoscopy: Current issues. World J Gastroenterol 2013; 19: 463-81.

5. Bilgi M, Tekelioglu UY, Sit M, Demirhan A, Akkaya A, Yildiz I, et al. Comparison of the effects of bispectral index-controlled use of remifentanil on propofol consumption and patient comfort in patients undergoing colonoscopy. Acta Gastroenterol Belg 2015; 78: 314-8.

6. James S, Broome IJ. Anaesthesia for cardioversion. Anaesthesia 2003; 58: 2912.

7. Lysakowski C, Dumont L, Pellegrini M, Clergue F, Tassonyi E. Effects of fentanyl, alfentanil, remifentanil and sufentanil on loss of consciousness and bispectral index during propofol induction of anaesthesia. Br J Anaesth 2001; 86: 523-7.

8. Ozkan G, Ince ME, Eskin MB, Erol G, Kadan M, Ozgur G, et al. Sedoanalgesia for cardioversion: comparison of alfentanil, remifentanil and fentanyl combined with propofol and midazolam: a prospective, randomized, double-blind study. Eur Rev Med Pharmacol Sci 2016; 20: 1140-8.

9. Toman H, Erkilinc A, Kocak T, Guzelmeric F, Savluk OF, Dogukan M, et al. Sedation for transesophageal echocardiography: comparison of propofol, midazolam and midazolam-alfentanil combination. Med Glas (Zenica) 2016; 13: $18-24$

10. Ho WM, Yen CM, Lan CH, Lin CY, Yong SB, Hwang KL, et al. Comparison between the recovery time of alfentanil and fentanyl in balanced propofol sedation for gastrointestinal and colonoscopy: a prospective, randomized study. BMC Gastroenterol 2012; 12: 164.

11. Tuncali B, Pekcan YO, Celebi A, Zeyneloglu P. Addition of low-dose ketamine to midazolam-fentanyl-propofol-based sedation for colonoscopy: a randomized, double-blind, controlled trial. J Clin Anesth 2015; 27: 301-6.

12. Turk HS, Aydogmus M, Unsal O, Isil CT, Citgez B, Oba S, et al. Ketamine versus alfentanil combined with propofol for sedation in colonoscopy procedures: a randomized prospective study. Turk J Gastroenterol 2014; 25: 644-9.

13. Rai MR, Parry TM, Dombrovskis A, Warner OJ. Remifentanil target-controlled infusion vs propofol target-controlled infusion for conscious sedation for awake fibreoptic intubation: a double-blinded randomized controlled trial. Br J Anaesth 2008; 100: 125-30.

14. Qadeer MA, Vargo JJ, Khandwala F, Lopez R, Zuccaro G. Propofol versus traditional sedative agents for gastrointestinal endoscopy:a meta-analysis. Clin Gastroenterol Hepatol 2005; 3: 1049-56.

15. Padmanabhan U, Leslie K, Eer AS, Maruff P, Silbert BS. Early cognitive impairment after sedation for colonoscopy: the effect of adding midazolam and/or fentanyl to propofol. Anesth Analg 2009; 109: 1448-55.

16. Phillips W, Anderson A, Rosengreen M, Johnson J, Halpin J. Propofol versus propofol/ketamine for brief painful procedures in the emergency department: clinical and bispectral index scale comparison. J Pain Palliat Care Pharmacother 2010; 24: 349-55.

17. das Neves JF, das Neves Araújo MM, de Paiva Araújo F, Ferreira CM, Duarte $\mathrm{FB}$, Pace $\mathrm{FH}$, et al. Colonoscopy sedation: clinical trial comparing propofo and fentanyl with or without midazolam. Braz J Anesthesiol 2016; 66: 231-6. 
18. Dumonceau JM, Riphaus A, Aparicio JR, Beilenhoff U, Knape JT, Ortmann M, et al. European Society of Gastrointestinal Endoscopy, European Society of Gastroenterology and Endoscopy Nurses and Associates, and the European Society of Anaesthesiology Guideline: Non-anesthesiologist administration of propofol for Gl endoscopy. Endoscopy 2010; 42: 960-74.

19. Vargo JJ1, Cohen LB, Rex DK, Kwo PY; American Association for the Study of Liver Diseases; American College of Gasteroenterology; American Gastroenterological Association; American Society for Gastrointestinal Endoscopy. Position statement: Nonanesthesiologist administration of propofol for GI endoscopy. Gastroenterology 2009; 137: 2161-7.

20. Hung A, Marshall J, Barnett S, Falchuk ZM, Sawhney M, Leffler DA. Risk Factors and Outcomes of Reversal Agent Use in Moderate Sedation During Endoscopy and Colonoscopy. J Clin Gastroenterol 2016; 50: e25-9.

21. Sathananthan D, Young E, Nind G, George B, Ashby A, Drummond S, et al. Assessing the safety of physician directed nurse administered propofol sedation in low risk patients undergoing endoscopy and colonoscopy. Endosc Int Open 2017; 5: E110-E5.

22. Aravapalli A, Norton HJ, Rozario N, Simpson J, DelGrosso B, Scobey MW. Increased Anesthesia Usage in a Large-Volume Endoscopy Unit: Patient Acuity Is Not the Main Predictor. South Med J 2015; 108: 547-52.

23. Baykal Tutal Z, Gulec H, Dereli N, Babayigit M, Kurtay A, Inceoz H, et al. Propofol-ketamine combination: a choice with less complications and better hemodynamic stability compared to propofol? On a prospective study in a group of colonoscopy patients. Ir J Med Sci 2016; 185: 699-704.

24. De Villiers WJ. Anesthesiology and gastroenterology. Anesthesiol Clin 2009; 27: $57-70$.

25. Allen M, Leslie K, Hebbard G, Jones I, Mettho T, Maruff P. A randomized controlled trial of light versus deep propofol sedation for elective outpatient colonoscopy: recall, procedural conditions, and recovery. Can J Anaesth 2015; 62: 1169-78. 